www.jmscr.igmpublication.org

Impact Factor 5.84

Index Copernicus Value: 71.58

ISSN (e)-2347-176x ISSN (p) 2455-0450

crossref DOI: _https://dx.doi.org/10.18535/jmscr/v6i1.165

Journal Of Medical Science And Clinical Research

IGM Publication

An Official Publication of IGM Publication

\title{
Possible Role of Renal Tubular Epithelial Cells (RTEC) in no Inflammatory Nephropathy
}

\author{
Authors \\ AK Kapoor ${ }^{1}$, Pooja Yadav $^{2}$, Surabhi Maheshwari ${ }^{3}$, Pratishtha Rastogi ${ }^{4}$, \\ Reetika Pandey ${ }^{5}$ \\ ${ }^{1,3,4}$ Pathologist, RML Mehrotra Pathology Pvt Ltd, Nirala Nagar, Lucknow, U.P., India \\ ${ }^{2}$ Senior Technician, Clinical Pathology, RML Mehrotra Pathology Pvt Ltd, Nirala Nagar, Lucknow, \\ U.P., India \\ ${ }^{5}$ Technician, Clinical Pathology, RML Mehrotra Pathology Pvt Ltd, Nirala Nagar, Lucknow, U.P., \\ India \\ Corresponding Author \\ Ashok Kumar Kapoor \\ D87 Mahanagar Extension, Vigyan Puri, Lucknow-226006, U.P., India \\ Email: drashokkapoor2016@gmail.com
}

\begin{abstract}
Present study relates to results of urinalysis of 3 patients. Microscopic examination of urine sediments revealed large number of renal tubular epithelial cells (RTEC). In addition, 1 of 3 cases also had significant mild albuminuria $(10 \mathrm{mg} / \mathrm{dl})$. Findings were suggestive of mild renal tubular injury.
\end{abstract}

\section{Introduction}

Renal tubules consist of proximal and distal tubules. Proximal tubules are relatively longer and more conspicuous compared with distal tubules. Furthermore, proximal tubules are lined by epithelial cells with brush border having microvilli. Later structures provide a large surface area for salt and water reabsorption ${ }^{1}$. Renal tubular epithelial cells (RTEC) appear to be preferred targets for certain toxins. In addition, RTEC have high rate of $\mathrm{O}_{2}$ consumption which further makes them susceptible to tubular injury ${ }^{1}$. Injury to RTEC leads to their excessive loss and focal denudation of tubular basement membrane. Present study relates to detection of large number of RTEC in urine sediments of 3 patients.

\section{Selection criteria}

Results of routine examination of urine samples from 1644 subjects with urinary complaints revealed detection of RTEC in urine samples of 35 subjects. Thirty two of 35 subjects also had pus cells. Later, these 32 subjects were excluded from this study (figure 1).

\section{Case Study}

Present study relates to the results of urinalysis of 3 patients. Age of the patients ranged from 28 to 34 (median 29) years. All the patients were females. The patients had large number of RTEC in their urine deposits. Table 1 shows the results of urinalysis of 3 patients. As it will appear, one of the patients also had mild proteinuria (proteins 
$10 \mathrm{mg} / \mathrm{dl}$ ) along with large number of RTEC in

conventional hematoxylin eosin method. urinary sediments. Smears were stained by

Table 1: Urinalysis of patients with large number of renal tubular epithelial cells $(n=3)$.

\begin{tabular}{|l|c|c|c|c|c|c|c|c|c|}
\hline $\begin{array}{l}\text { Case } \\
\text { No. }\end{array}$ & Patient ID & $\begin{array}{c}\text { Age in } \\
\text { years }\end{array}$ & Sex & $\begin{array}{c}\text { Renal tubular } \\
\text { epithelial cells }\end{array}$ & $\begin{array}{c}\text { Pus } \\
\text { cells }\end{array}$ & RBC & Sugar & $\begin{array}{c}\text { Protein } \\
\text { mg/dl }\end{array}$ & pH \\
\hline 1 & 10130949 & 34 & F & $5+$ & - & - & - & - & 6.5 \\
\hline 2 & 10131587 & 29 & F & $3+$ & - & - & - & 10 & 6.5 \\
\hline 3 & 10139236 & 28 & F & $4+$ & - & - & - & - & 7.5 \\
\hline
\end{tabular}

Abbreviations: $3+=11$ to 15 cells/hpf, $4+=16$ to 20 cells/hpf, $5+=>20$ cells/hpf,

$\mathrm{F}=$ female

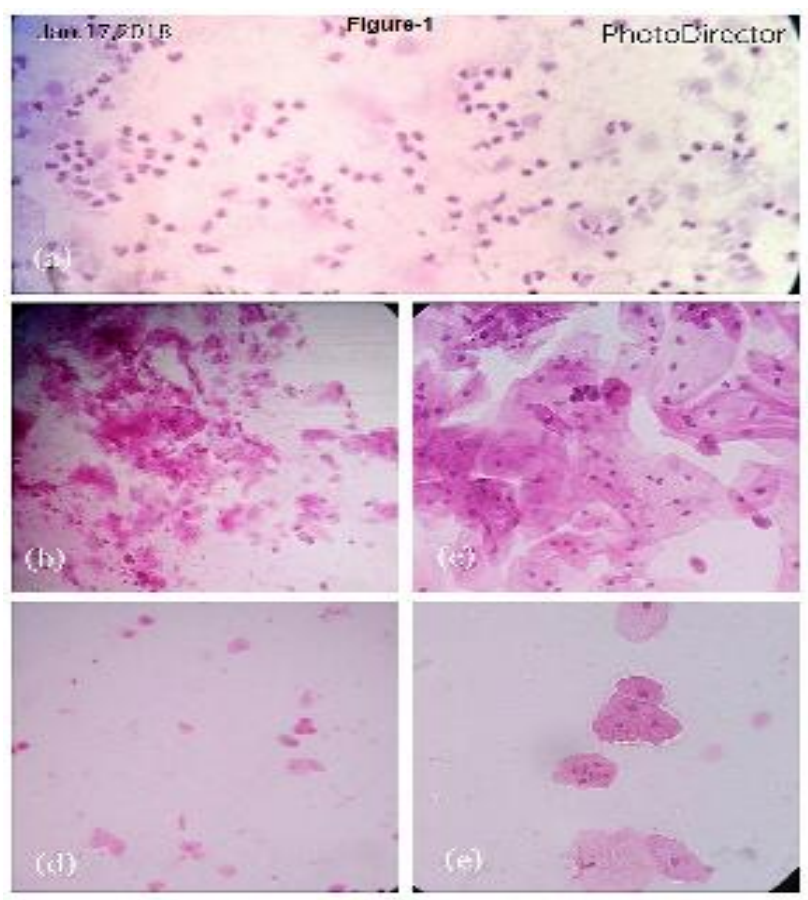

Figure 1 (a) showed large number of neutrophils and pus cells in urine sediment of a subject (HE $\times$ 100). (b) showed neutrophils and renal tubular epithelial cells (RTEC) in centrifuged deposit of another subject $(\mathrm{HE} \times 100)$. (c) High power magnification of urine deposit of previous subject $(\mathrm{HE} \times 450)$. (d) Urine deposit view showing few neutrophils sticking on the surface of infected epithelial cells $(\mathrm{HE} \times 100)$. (e) Higher magnification of urine sediment of previous subject $(\mathrm{HE} \times 450)$. Subjects with pus cells in urine deposit were excluded from the present study.

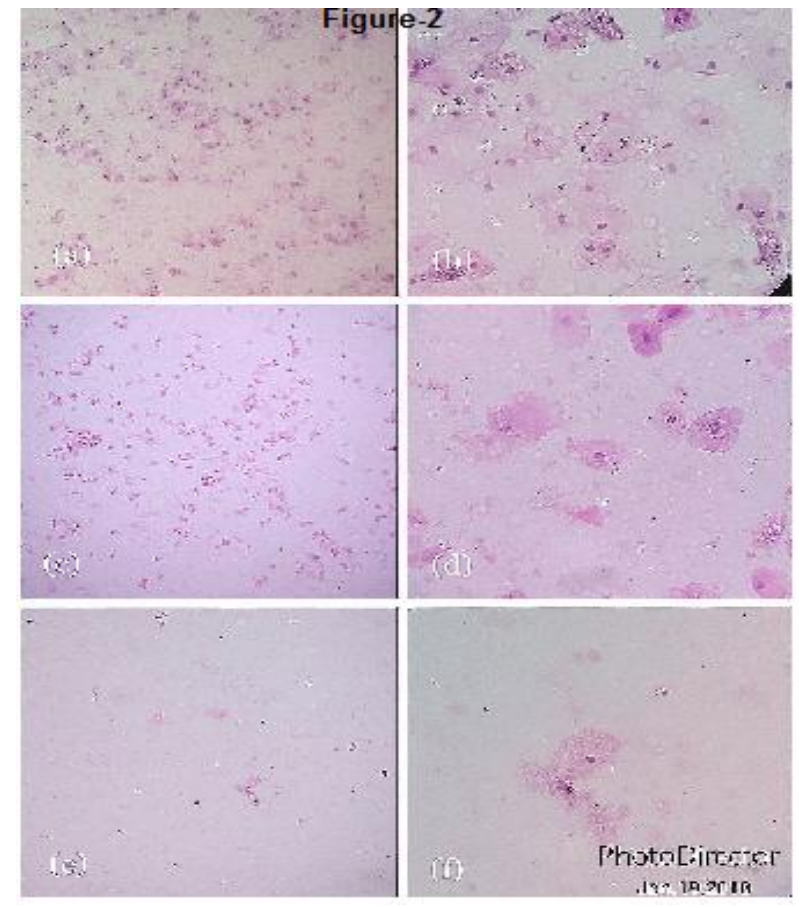

Figure 2 (a), (c) and (e) showed lower magnification of urine deposits from 3 patients included in this study $(\mathrm{HE} \times 100)$. (b), (d) and (f) showed higher magnification of urine deposits of patients which were included in present study (HE $\times 450$ ).

\section{Discussion}

Most important feature of this study was the detection of large number of RTEC in urine sediments of 3 patients. Moreover, one of 3 patients also had mild proteinuria. Loss of large number of RTEC in urine and mild proteinuria suggested possible injury to tubular epithelium. Absence of leucocytes and pus cells in centrifuged urine deposits of 3 patients suggested role of noninflammatory agents in pathogenesis of tubular 
nephropathy. Nonbacterial factors, e.g. exogenous toxins and immunological and metabolic dysfunctions appear to be involved in loss of large number of RTEC in urine sediments ${ }^{2}$. In addition, interrupted blood flow or ischemia might have contributed to renal injury and loss of tubular epithelial cells ${ }^{3}$. Moreover, proximal tubular injury may also lead to mineral bone disorder and anemia $^{4}$. Furthermore, RTEC appeared to form a barrier between the host and ascending urinary tract infection ${ }^{5}$.

\section{Conclusion}

Present study relates to the results of urinalysis of 3 patients having renal tubular epithelial cells (RTEC) in urine sediments. One of the patients also had mild proteinuria. Significant mild proteinuria in association with loss of large number of RTEC suggested mild tubular nephropathy.

\section{Financial support and sponsorship: Nil}

Conflicts of interest: There are no conflicts of interest.

\section{References}

1. Jennette JC, Spargo BH. The kidney, chapter 16, In Pathology, Rubin E, Farber JL (editors), $3^{\text {rd }}$ edition, Lippincot-Raven publishers, Philadelphia, p 861-918, 1999.

2. Brenner BM, Hostetter, Hebert SC. Tubulointerstitial diseases of the kidney. In Harrison's principles of internal medicine volume 2. Braunwold E, Isselbacher KJ. Petersdorf RG, Wilson JD, Martin JB, Fauci AS (editors) $11^{\text {th }}$ edition, McGraw-Hill book company (publisher) New York, p 1195-1200, 1987.

3. Alpers CE, Chang A. The kidney tubular and interstitial diseases. Acute tubular injury/necrosis. Robbins and Cotran Pathologic basis of disease volume II Kumar V, Abbas AK, Aster JC (editors)
Reed Elsever India Pvt Ltd (publisher) $\mathrm{p}$ 927-929, 2015.

4. Nakhoul N, BatumanV : Role of proximal tubules in the pathogenesis of kidney disease. Contr Nephrol 2011; 169 : 37-50.

5. Nitschke M, Wiehl S, Baer PC, Kreft B. Bactericidal activity of renal tubular cells The putative role of human $\beta$-defensins. Experimental Nephrology 2002; 10 : 332337. 